\title{
International Organisations' Efforts on Fighting Corruption in Albania. Success or Failure?
}

\author{
MA . Kloida Dashi \\ Tirana, Albania
}

\section{Doi:10.5901/mjss.2014.v5n2p371}

\begin{abstract}
This thesis will first explore the question of to what extent has official corruption been prevalent in post-Communist Albania, and whether reform efforts in those countries have been successful. Albania desires to become a member of the EU, but its efforts have been seriously compromised by the unacceptable level of official corruption. Exploration of this first question will necessarily involve a background discussion of the political culture of corruption in Albania during the pre-Communist, Communist, and post-Communist eras. This discussion is necessary to discourage any idea that the issue of corruption became a major problem in Albania only after the emergence of post-Communist capitalism. While the collapse of Communism created spectacular opportunities for corruption throughout the post-Communist region, official corruption did not just suddenly appear for the first time then. Rather, as will be discussed in detail, as all acknowledged academic authorities make great effort to point out, throughout the twentieth century, and even before, official corruption had dominated the politics in this country, and reappeared in public following the fall of Communism.
\end{abstract}

Keywords: Corruption, Albania, International Organizations,

\section{Introduction}

\subsection{Objective}

The theme of official corruption in the Balkans is a recurrent one, and becomes particularly relevant in an era where Europe is attempting to be more unified, both institutionally and economically. In such an era of unification, Europe understands that no European-wide unity is possible without the inclusion of the Balkans, yet it also understands that a unified Europe is only as strong as its weakest links, and Europe cannot afford a corrupt, closed and unreliable Balkan region as its "weak link". At the same time, power elites in the Balkans desire further integration into the rest of Europe for obvious economic and security benefits. However, these very same power elites have been embedded in official cultures of corruption and favoritism, and thus resist the reforms needed to make their countries more acceptable to the rest of Europe because of their fear of losing the advantages that such corrupt systems have exclusively given them.

The fall of Communism in Eastern Europe over twenty years ago, at that time, appeared to present a unique opportunity for European unity. However, Europe today remains far away from the one unified state as dreamt by Europe's "father", Schuman: "... All Europeans without distinction, whether from east or west, and all the overseas territories... The gathering of the nations of Europe... a first step for the European Federation..." ${ }^{1}$ Although considerable progress has been made by the rise of the European Union, major obstacles remain. Prominent among these obstacles has been the corruption issue in the former Communist nations, including the Balkan nations, where a narrow group of elites has continued to be in power before and since the fall of Communism.

\subsection{Motivation}

Ample academic sources exist with respect to the continuous treatment of corruption as part of the historical political culture of Albania. On the other hand, academic works focusing upon the current issue of corruption in these countries are scant, as well as academic treatment of international anti-corruption efforts. Indeed, while doing my own research, I specifically noted the limited sources upon which the few available academic accounts relied and cited

This, however, does not mean that an examination of the problems posed here has to be abandoned. A wealth of

1.http://www.cvce.eu/obj/la_declaration_de_robert_schuman_paris_9_mai_1950-fr-d27938ef-7d39-4d32-b340-07fe7268e3c3.html 
primary sources, including web-sites of various international entities, newspaper accounts, (both within and outside of Albania) and official published legal decisions, among others, provide documentary evidence, which, combined with the consistent findings of prior academic writers, provide a framework to approach these issues within an academic setting. It is further submitted that this "problem" can turn into an "opportunity", by conducting original research with reliance on primary sources, instead of only repeating the conclusions already made in secondary sources.

Thus, using prior solid academic writings as the background to the entire history of corruption, this thesis will describe international efforts at reform primarily from documentary sources. Accounts from domestic media and legal sources will be used. In addition, as a tertiary source, is my own experience, because I have worked with internationals in connection with reforms within the Albanian National Chamber of Advocates.

Against this general background, what this thesis will address should be clear. First, it will provide the needed relevant consistent academic findings, which tie corruption in Albania to a firmly established political cultural tradition. Next, it will examine how Albanian public opinion and international entities view this problem of corruption and how they have attempted to conquer it. The thesis will then focus upon very specific instances of corruption, not only to shed light on how corruption manifests itself there even today, but also as examples were international entities had a significant or insignificant impact. Finally, the thesis will end with a discussion as to how successful international involvement has been in battling corruption in Albania. What has worked for the internationals and what has not? How successful have international efforts been in persuading the power elites to abolish a corrupt culture of corruption-a culture which has worked only in the interests of these very same power elites themselves? And, if there has been any diminishing of corruption to any extent, is this due to a more informed Albanian public, or the presence of international anti-corruption programs, or both?

Very connected to the issue of attempts at reform of official corruption is the role international efforts, specifically European and American efforts, have played in the implementation of actual anti-corruption progress in Albania. This thesis will discuss the specific programs enacted by international attempts to address the issue of corruption, as well as discussing the issue of what, if any, practical difference, such international programs have made upon the elimination or reduction of official corruption.

Assuming that any progress has been achieved in reducing corruption in Albania, this thesis will finally discuss to what extent progress to be credited to domestic efforts and a more informed public opinion, and to what extent progress should be credited to international efforts. Put another way, the thesis will also discuss those instances of failed anticorruption efforts and how much blame, if any, should be put on international entities for these failures.

\subsection{Definition}

The term "official corruption, when applied to the power elites in Albania, has not created any difficulty of definition for any writer on the subject. According to Wikipedia the word corrupt is defined as follows: (Middle English, from Latin corruptus, past participle of corrumpere, to abuse or destroy : com-, intensive pref. and rumpere, to break) when used as an adjective literally means 'utterly broken'; the EU's own definition of corruption is "abuse of power for private gain"2. This definition borrowed from the Global Program Against Corruption run by the United Nations, and includes both the public and private sector.

As a legal definition, corruption is an act done with intent to give some advantage inconsistent with official duty and the rights of others. It includes bribery, but is more comprehensive than that because an act may be corruptly done, though the advantage to be derived from it is not offered by another.

In academic literature, we find many definitions and types of corruption, but the most common ones are bribery, nepotism, fraud, embezzlement. This thesis incorporates all of these four types of corruption in its discussion.

\section{Background}

\subsection{Background - General}

Corruption has been a major issue for the fragile countries in Eastern Europe emerging from the Communist era. Since Communism's collapse, these states have been tried to establish working institutions for representative democracy and a functioning economy. Some countries have performed better than others. For example, Poland, Hungary, the Czech

\footnotetext{
2 http://www.cgu.gov.br/onu/publicacoes/Arquivos/Toolkit.pdf
} 
Republic, and Slovenia only needed short periods of time to resemble western democratized countries. For them, fulfilling the Copenhagen criteria (established by the European Council in 1993) for the stability of institutions that guarantee democracy, human rights, rule of law, the existence of a functioning market, etc., was a process that was completed by 1 January 2004, when ten states joined the EU.

In contrast, Albania, Bosnia and Herzegovina, and Macedonia, among others, have made little or no progress. In fact, the states comprising the Western Balkans have been treated specifically by the EU with the Stabilization and Association Process, a program which deals with the special backwards circumstances of corruption and lack of transparency there. These special circumstances are the reasons why some post-Communist countries have advanced so far, while these countries have not. Although Romania has become a member of the European Union, no one seriously believes that it has made the progress of Poland, Hungary, or Slovakia.

Various scholars, both in the past and currently, are consistent in assigning reasons for these "special circumstances". From classics in the field of East European Studies, such as Hugh Seton-Watson's in "Eastern Europe Between the Wars' (Seton-Watson 1962, pg.4) to more modern authorities such as Janos, Stark and Bruszt, explain that the differences between East European states are based primarily on different political cultures. Also, in their studies, Jeffrey S. Kopstein and David A. Reilly (pg.3) emphasize the importance of geography. Countries closer to the west receive constantly high scores on political and economic outcomes. According to them, countries closer to the West are more open to outside democratic and transparent ideas. On the other hand, statistics indicate that the further away a country is from the West, the less likely it is democratic, and low levels of democracy correlate to high levels of corruption.

A very valid reason for this geographic difference is that all countries in the Balkans have a common Ottoman heritage of autocracy and corruption, which will be further discussed.

\subsection{Background - Albania}

Albania did not obtain its independence until 1912. For over 500 years, it was under the control of the Ottoman Empire, and a culture of official corruption became normal behavior. (Wolff-1967, pg.142) After a brief unsuccessful Social Democrat government, pre-War Albania was led by Ahmed Bey Zogu, who, while creating some modern facilities, allowed corruption and bribery in the award of public contracts to dominate. Professor Robert Lee Wolff of Harvard University described the corrupt atmosphere under Zog as follows:

"Zog's regime was a curious mixture of Ottoman corruption with strivings towards westernization and improvement. [The] harbor at Durazzo... had already been improved at such cost that one would have expected it to have had installations as impressive as those along the Hudson or the Thames. That it continued to need improvements was suggestive of the way in which funds vanished in the Balkans." (Wolff 1967)

Corruption and bribery in Albania were therefore very widespread. During the Communist era, corruption in Albania was not publicized, due to the closed nature of the system. However, the undisputed wealthy lifestyles of the Communist leaders of the nomenklatura demonstrate how they profited from their positions. They and their relatives lived in huge 'super luxurious' villas, especially in comparison with the rest of the public. They had holidays in special places, not opened to the public, such as along the Ionian coast and Lake Ohrid. Their children were the only ones permitted to study abroad and the Party elite were able to obtain medical treatment abroad as well. Further, they used the government's fancy cars in a place where private property was almost completely forbidden, including cars. Everyone knew about these things but no one dared to speak. Because of the harsh Communist dictatorship people had such a mistrust of others, were socially isolated and lacked civic awareness. Just as during the Ottoman and pre-Communist eras, the mentality was that public posts were sources of profit, and this led to a low level of respect for the state and the law, because: first, people found it unfair; second, for reasons of cultural tradition; and third, because of poverty.

\section{Corruption in Albania from the 90 's till Today}

\subsection{Corruption under Berisha in the 90's and Nanos in the early 2000s}

In Albania, the fall of Communism in 1990 resulted in an unprecedented influx of trafficking and organized crime to the EU. As Bogdani and Loughlin explain, the reasons for this are as follows: - first, the poverty of Albania, (it is one of the poorest countries in region) and; second, its geographic position at a crossroads where much trafficking takes place. Many reports by international organizations have pointed out that corruption and organized crime are endemic, and, of 
course, this prevents institutional and economic development, thereby seriously threatening the stability and progress of the country. (Bogdani; Loughlin-2007, pg.149)

Today Albania is a parliamentary state system, and from 2005 till 2013, the party leading was the Democratic Party, founded 1 December 1991, and led by Sali Berisha (1991-1992; 1997 up to 2013). He was a doctor of Albania's dictator Enver Hoxha, and from 1969 to 1990, he was a high member of the Communist Party (Labor Party of AlbaniaPPSH), being a Party Secretary. ${ }^{3}$ The first free elections in 1992 made him President of Albania for the period 19921997.

During the 1990s, Albania established a close cooperation with the European Union and the United States, and opened itself to the West. It became a member of the European Council in 1995, and signed the Partnership for Peace and Agreement in 1993. Many reforms took place to replace all the old laws with new ones.

During the time he was president from 1992 to 1997, Berisha allowed Ponzi saving schemes to grow, (where more than 2 billion US dollars of life savings of Albanians were invested). The system collapsed in 1996, and all the people were protesting in the streets by accusing the government of stealing their money (Woods-1997). As a result of the popular demonstrations, more than 2000 people were killed, and it was almost a civil war.

One British visitor to Albania in 1996, Robert Carter, in his book (Carter -1998 pg.171) was exceptionally critical of corruption during the first Berisha era, calling it a "corrupt begger state". Carver compared Albanial to post-colonial Africa and Latin America, saying that Albania, also, had a foreign-aid industry which really only helped the corrupt elite get richer and stated as follows:

..."'communism has been rejected for "capitalism', but in fact little had changed: the people were still locked into a dependency on foreign patrons, and a feudal subordination to a domestic elite which lined its own pockets at the people's expense; which fuelled all this was foreign aid"

Although the system did collapse in 1996, the corruption under Berisha had created an outcry by the public earlier in 1995. For the first time, public opinion in Albania was not going to accept corruption as just "part of the system" and the incident that started this was the near-fatal attack on a leading newspaper publisher, Nikolle Lesi at his home in Lezha. Miranda Vickers and James Pettifer described this public anger:

"As happens throughout the world, an increased level of material corruption in politics led to rising public concern...many Albanians feels that corruption has moved to the heart of the state machine...In response to the reaction from the public, Berisha announced a crackdown on corruption but too little obvious effect." (Vickers, Pettifer2000, pg.271-272)

As a result of the widespread corruption and scandals, Berisha and the Democratic Party were swept out of power by Fatos Nano and the Socialists in 1997. However, with the exception of the absence of another nation-wide Ponzi scheme, honesty and transparency in government were also largely missing in the Nanos governments. It was as if one set of corrupt party politicians simply replaced another set. In fact, the public was so disgusted that it started to listen to Berisha again, in spite of the disasters of the $1990^{\text {s. }}$.

Incredibly, Berisha came in power again with the elections of 2005, this time as head of government, and since that day he is somehow involved in all the corruption scandals in Albania. Now, however, the accusations do not include just Mr.Berisha but even his family, mostly his daughter Argita, and his son Shkelzen. Berisha's Democratic Party showed gains in the election of 2005 and maintained power after the close election of 2009, in spite of many protests that the election was rigged. In the May 2011 elections, because of the continued instances of corruption, the Socialists won $70 \%$ of the local positions open for election, although the Berisha candidate for Mayor of Tirana, Basha, "defeated" Edi Rama in a close, and very suspicious, election, which remains in dispute. The OSCE election reports for both 2009 and 2011 specifically noted the high mistrust between the Democratic Party and the Socialists, reflecting also the high mistrust of the public of the election process because it still thinks the results are always "rigged".

\subsection{Corruption in Albania today (till before the elections of 2013)}

Naturally, such an atmosphere as described above will have its own consequences for a long time. This is one of the reasons why politicians in Albania are so corrupt. Further, the persons leading Albania today are the same ones that were power elites in old times as well. Government salaries today are low, but even if they were higher, they could not

${ }^{3}$ Encyclopedia of World Biography 
live at the high standards they are used to without corruption. Consider not only the members of the Council of Ministers taking so many bribes for major favors or for winning tenders, but also consider the judges in Albania. Their salary is in average 500 to $600 € /$ month. This amount of money sometimes is not even enough to cover their mobile expenses. The question that naturally comes on mind is, how can they cover the expenses for children to study in the best private schools inside or outside Albania, and how can they afford to have the latest fancy car? How is it possible that they are having their holidays with their families in the most expensive and luxurious places in the world?

More or less the same questions have to be asked even for other public administration personnel. This does not require an academic article or a deep investigation because this is a matter of common knowledge in Albania. Everybody knows how the system works. So, the only logical answer is that "citizens and businesses are forced to pay bribes at all levels of the administration in order to save time and to get things done". (Bogdani, Loughlin-2007, pg.152)

The biggest problem here is that even if officials are investigated and charged with corruption and bribery, they somehow achieve to get the case dismissed before it goes to the courts, because they have enough money to bribe prosecutors, or mostly, judges. Many corruption scandals have been made public in all the newspapers, and TV programs, but nobody has gotten sentenced so far. Finally, these same people are seen switching from one government position to another.

That is why fighting corruption in Albania has become very hard work, and some time it even seems like an impossible labor. According to international survey, which includes data from the World Bank and Transparency International, $70 \%$ of all Albanians pay bribes for several things in several fields, like bribes for not getting a penalty, bribes for having a new job, bribes at hospitals, and bribes for fiscal or customs services. Paying bribes has become so common that, for most people, it seems like a normal thing to do. They see it as an obligation, as something that everybody does, as something that is a concurrent part of the system, and as something without which nothing can be done properly. Worst, they see it as a moral norm.

The public is aware of the problem, but it considers it as an unwritten rule, and this is what makes fighting against corruption so difficult. Many analysts on TV take the courage to denounce it, like the political analyst Andrea Stefani (2004), which considers this blatant corruption of the politicians as 'spectacular and one of the forms of the arrogance of those in powers', but all that happens afterwards are legal charges against publishers, journalists and civic groups.

In every gathering or public showing, in TV, or even from the Parliament's pulpit, opposition leaders of both sides (Socialist Party) (Democratic Party) label each other as 'Communist', 'criminals', 'enemy of democracy', 'corrupt' and so on, but none of them has ever been convicted, (Peci, Sikkemaa-2010, pg.101-118) and none of the accusations are taken for real, no matter what the evidence shows. In all the indicators, Albania, in terms of Institutional Quality, and in terms of corruption, rule of law, and integration to the world economy, is rated extremely low compared with the other countries in transition.

Comparing 2005, when Transparency International Corruption Perceptions Index', gave Albania a score of 2.4 out of 10 (where 10 is the least and 0 is the most corrupt) and ranked it 126 out of 158 countries, the same Index in 2010 did show some improvement scoring Albania 3.3 out of 10, and ranking it 87 out of 180 countries. This is still very unacceptable for a European nation desiring to enter the European Union.

Another common corrupt phenomenon in Albania is "clientelism". According to Furlong clientelism refers to the use of state resources of various kinds to develop personal electoral support and is wide-spread phenomenon in Albania (Furlong-1994, pg.295). As noted earlier, even during Communism, the system of favors, exchanges and support from "a friend" in getting jobs or things done was very strong. Worse, a dictatorship ruled the country, and being the relative of a high- level person, would open all of one's doors, no matter how illiterate one was.

Today, we may speak of democratic institutions, competition, skills, human rights, etc., but the fragile democracy of Albania remains infected by clientelism. This involves power relations and the manipulation of state institution in the interest of the people in power, and structures the system around informal networks of personal relationship based on the exchange of favors. (Bogdani, Loughlin-2007, pg.150).

The corrupt system works as follows: when a political party comes into power, it forms the government, and after this, every single minister changes its staff by putting into positions of responsibility militants of the party, who have "invested" in elections, and to whom it was promised a place of work for themselves or their relatives. By this system, all the professionals (especially the ones supporting the party already in opposition) get fired and the ones that have no experience take their places. This is bad for the well functioning of the institutions, because people without any job experience, or unqualified ones, are working in very important administrative positions. This can negatively impact upon any attempt to competently run the economy of the state. The people that were fired must try to litigate to obtain any decent work, because, in the best of the times they cannot even get an official document with the 'reasonable' reasons 
why he/she was fired. They generally win their legal cases, but corruption within the government in Albania often makes these "victories" worthless or, at least, less valuable. No official will respect the court's decision, and judicial decisions are never implemented because nothing correctly functions. Making matters worse, the position in question has already been taken, or the process drags on for a long period of time and the victorious litigant, instead of a position, is given the salary of one year and some other extra month salaries for holidays, or the "13-th salary"4. Therefore, what happens is that the state, for at least one year, is obligated to pay two salaries for the same position-one for the person working, and another one for the other that was unlawfully fired. Although this is an absurd result in any country, it is especially absurd in a poor country like Albania.

Another scholar, J. Newell states that clientelism is encouraged by specific economic, political and social circumstances: poverty, unemployment, new and weak democratic state institutions, suspicion and mistrust that make collective action difficult (Newell-2001, pg.45). This can only result in a malfunctioning state. Such abuse of the system by the political power elite, both centrally and at the local level, allows their supporters to profit from government benefits and services, as a "reward". Likewise, new businessman and entrepreneurs who supported the "winning" power elites can obtain licenses, contracts, and tenders without any regular procedure.

\subsection{International efforts to fight corruption in Albania}

\subsubsection{Operation Pelikan}

Since 1990, the West welcomed Albania's efforts to cooperate and become a part of it. The EU presence in Albania started with a humanitarian aid mission led by Italy, known as "Operation Pelikan". The first contractual agreement with EU was the Cooperation of Trade and Agreement in 1992. The European Union, in that time, offered more than $\$ 500$ million in loans to Albania. However, no matter the rapid economic growth since 1993, the Albanian economy itself remained impoverished. The aid from the EU ended up in the pockets of speculators, crooks, and of course, the ruling Democratic Party, while the badly run-down infrastructure and industry was starved of investment. Wealth for the few, impoverishment for the many - that was the picture in Albania, as well as the other ex-Stalinist states. Albanian roads were full of used Western cars and in many houses spotted satellite dishes. Despite grandiose plans for developing the country's infrastructure, it has decayed rapidly, while wealth has been concentrated in a few dishonest pockets." (Woods1997) So, as may be seen from this first analysis made by Professor Woods, since the first moment the Democratic Party came in power, the corruption blossomed. The internationals were aware of it, and so they (especially the countries of the EU and the United States) started helping Albania with different kind of projects to fight corruption- a cancer that has caught the system, and the internationals did not wanted to have it spread further. Therefore, many international organizations, e.g., NATO, CoE, OECD, IFM, WB etc., have been trying for so many years to influence domestic changes.

\subsubsection{SPAI}

Another important project for countries in transition facing threats of a widespread administrative and political corruption affecting government and society is SPAl, a project launched by OECD and implemented in 2003. The members are Albania, Bosnia and Herzegovina, Croatia, the Republic of Macedonia, Republic of Moldova, Republic of Montenegro, Republic of Serbia, and Romania. The Republic of Montenegro joined the SPAI in February 2000 and the Republic of Serbia in December 2001.

As reflected in the many academic articles, which generally discuss the issue of corruption in South-East Europe, fighting against it has been declared a priority by all the governments of the members of SPAl. However, the speed of the reform process for some countries was high, but for most of them it was not. These reforms have to do mostly with economic, political and legislative reforms. Almost all of them have chosen a multi-disciplinary approach and developed the so called "omnibus programs" that generally entail some combinations of the following: a concept document, an anticorruption law, a dedicated agency or inter-ministerial commission, an action plan to implement the program, and a monitoring mechanism.

\footnotetext{
${ }^{4}$ Albanian Labor Code article 130 and on
} 


\subsubsection{PACO}

The CoE has been involved in the establishment of anti-corruption structures since 1999. In March 2004, it launched a program named PACO, a project that ended in 2006. For Albania, the fund was 1.5 million $€$, financed mostly from Germany and Italy. This program's objective was to strengthen democracy and the rule of law in South-Eastern Europe through the prevention and control of corruption. Mostly this project was dealing with anti-corruption plans, institutional mechanisms for the monitoring of anti-corruption plans, and draft laws available to bring the criminal legislation on corruption in line with European standards. One of the attractive ideas of this project was PACO IMPACT trying to work with technical experts' level inside the respective administrations. They were hoping that this level is not that much involved with politics. However, as explained earlier, the power elite simply, by changing the head of the Ministry, or by changing the Directory General 'old' staff and replacing them by 'new' ones, kept real power in the hands of the "political" and the project therefore has not met the hoped-for results. In spite of this, the final report, presented in Strasbourg, 1011 July, 2006, congratulated itself and called the program a complete success .

\subsubsection{CARDS}

After this program, EU applied a new one for the countries of the Balkans named CARDS, which replaced all the previous once, with an amount of 4.6 billion $€$.

As in almost all other Balkan countries, even in Albania, this program was focused on 5 important areas:

- Democratic stabilization (about 5\%)

- Good governance and Institutional Building (Justice and Home Affairs, about 40\%)

- Administrative capacity building (about 20\%)

- Economic and Social Development (about 30\%)

- Environment and Natural Resources (about 5\%) (Bogdani;Loughlin-2007, pg.215-217)

This program was in effect for the period 2000-2006. Meanwhile, American governmental organizations, especially USAID, were also active in Albania. This organization played and still plays a very important role in Albania, together with the European ones.

USAID, in cooperation with IPL, has assisted in Administrative Law proposals (2000), Citizens Guide to Albanian Judicial System (2001), Electoral Code Commentary (2001), Legal Systems that Better Support Democratic Processes and Market Reforms (2003), Millennium Challenge Account Program -"Business Registration Component" (2006), and many other projects on its own or in cooperation with locals. They were focused on all areas under USAID Democracy and Governance programs, notably rule of law, anti-corruption and civil society development. ${ }^{5}$

\subsubsection{GRECO}

Since October 1997, the Heads of States and Government of the Member States of the CoE, has decided to have a common response to the challenges posed by the growth in corruption and the organized crime, so in March 1998 they approved a draft agreement establishing the GRECO and in May 1998, enacted by the Committee of Ministers ${ }^{6}$. GRECO was set up by the following 17 founding members: Belgium, Bulgaria, Cyprus, Estonia, Finland, France, Germany, Greece, Iceland, Ireland, Lithuania, Luxembourg, Romania, Slovakia, Slovenia, Spain, and Sweden. ${ }^{7}$

GRECO evaluates states by following the 20 Guiding Principles. For example, Principle 3 deals with authorities in charge of preventing, investigating, prosecuting, and adjudicating corruption offences, while Principle 7 covers specialized persons dealing with corruption.

In 2002, GRECO made the first evaluation of Albania. According to this evaluation, Albania somehow overcame the bad experience of the time of the "Ponzi pyramid", and was trying to build the State and the institutions. Page 6, point 23 of the evaluation noted, "The fight against corruption in Albania has often been used primarily as a tool in the political environment between the ruling party and the opposition or between factions within political parties... There is a low level of trust by the public in the impartiality of the courts... zero-trust in the public institutions..." but it did further note that a

\footnotetext{
${ }^{5}$ http://www.ip/s.org/Projects.html

6102 Session-Strasbourg

${ }^{7}$ www.coe.int/greco Any State which becomes Party to the Criminal or Civil Law Conventions on Corruption automatically accedes to GRECO and its evaluation procedures. Albania is part of GRECO since 27.04.2001. Currently GRECO includes 49 states; 48 European States and United States of America.
} 
part of the society had begun to consider corruption as a heavy cost for the Albanian society. This is a good thing if we take into consideration the WB's report in 1998, where Albania was considered one of the most corrupt countries in Europe, and it was also excluded from TI's ranking as a result of a lack of information.

After a wide overview of the Albanian situation in all the vital sectors of the state, GRECO in its evaluation stated the reasons for this high level of corruption, among others, as follows: low salaries of judges, prosecutors untrained in corruption, political influence, and bribe mentality. The conclusion of the evaluation recommended to the Albanian government reforms including the following: amendments to the National Anti-Corruption Plan involving civil society and the business sector in the activities of the ACMG; improvement of the transparency of public authorities vis-à-vis media and public accession; a specialized education of the police, prosecutors and juridical police on corruption and; a reduction in the list of categories of officials covered by immunity and/or a reduction in the scope of immunity to a minimum.

In this report GRECO invited Albanian authorities to implement the recommendations by 30 June 2004.

After this first evaluation, enactments of new laws and amendments to old ones were necessary to implement the evaluation's recommendations. More specifically, after the 06/07/2000 civil convention "for Corruption" was ratified, many institutions were needed in order to be in able to implement it. Thus, many enabling laws were passed in Parliament and the legal framework was almost complete: Criminal Code (1995 with amendments in 2003) Criminal Procedure Code (1996 with amendments in 2003) State Police Law (1999 with amendments in 2002 and 2003) Prevention of Money Laundering Law (May 2000 amended in 2003) Prevention and Fight against Organized Crime (September 2004) Declaration and the Control of Assets, Financial Obligations of the Elected and some Public Officials (April 2003), AntiMonopoly Law (July 2003), Rules of Ethics in Public Administration (September 2003) and a host of others. The best legal reforms derived from the directives of the COE through the GRECO recommendations.

One of the laws considered as effective in fighting against corruption, was the Law on Nonprofit Organizations, and enacted by the Albanian Parliament in May 2001, together with the Law on the Registration of Non-Profit Organizations, as accompanied by the Civil Code amendments. The enactment of these laws was possible due to the technical assistance of USAID in supporting the development of them.

Thus, Albania had the whole legal framework in place in its laws for fighting corruption, with the above noted international assistance. What remained and remains the central challenge is the actual effective implementation and enforcement of these laws.

In order to conform to international norms, the Prime Minister decided to open up participation in the ACMG to members of society, by allowing the ACAC and the business Community to participate, by opening all the board meetings to the public and media. The establishments of ACAC and of the CAO in Albania were sponsored by the US government, providing funding of 2.1 million US dollars. (Basel Institute 2005, pg.7)

After the first evaluation done by GRECO, Albania was trying to follow the recommendations therein. Much was done during this period, but the resulting second evaluation noted that all of the problems remained almost the same. This second evaluation opined that corruption remained one of the main concerns in Albania, which also faces other types of serious criminality, such as organized crime, trafficking in human beings, drug trafficking, smuggling etc. (Gerassimos, Eline-2005, pg.15) The second evaluation did state that some progress was achieved in the transparency in the operation of governmental bodies and their cooperation with civil society and the business community. Further, many new institutions had been set up, such as the High Inspectorate for Declaration and Control of Assets, which, in the GET's view, had the potential to contribute to the fight against corruption and the detection of corruption proceeds in an effective manner, People's Advocate, Internal Audit Directorates (Basel Institute-2005, pg.2) . Interestingly, the second evaluation noted the overlapping of many laws and the continued need to actually implement and enforce the laws in place.

After the two first evaluations, GRECO did the third evaluation in Strasbourg 15 May 2009. This evaluation found that Albania has adjusted all the domestic laws in order to bring them into line with the body of European law built up over the history of the Union, known as the acquis communautaire. Of course much still needed to be done. The Criminal Code was adjusted by including active and passive corruption of persons exercising public functions, (art.244, 259), high State officials and of locally elected persons (art.245, 260), judges, prosecutors and employees of the judicial body (art.319, 319/a). The section 312 C.C. penalizes the direct or indirect proposing, offering, or giving any kind of gift or bribery (art.321 CC). Also, as contemplated in these articles, even the traffic of influence, a promise against a candidate, or abstaining from taking part in the elections (art 328 CC) were forbidden. Obviously therefore, after all of the 2004 legislative reforms, the intention was to conform the national legislations to international standards, as required, inter alia, by the Criminal Law Convention on Corruption that was ratified in 2001. 
A general analysis of the above three GRECO evaluations demonstrate that the Albanian Parliament, with international assistance, did pass and enact suitable laws to address all aspects of corruption and those laws were drafted in accordance with European norms. However, passing the laws is one thing; actually implementing and enforcing them is quite a different matter. Thus, it alone cannot be taken as a sign of commitment by governments to tackle corruption, or more importantly, their effectiveness in rooting out the problem. The irony is that while Albania has modern and progressive laws dealing with the entire issue of corruption, both in the way the laws are implemented (or, more accurately, not implemented) and the way the Albanian judiciary has handled matters brought before it pursuant to these laws, demonstrate an almost complete lack of will or desire to actually use the legal tools now available in Albania to prosecute corruption matters.

\section{Conclusions}

What, then, does the evidence tell us about the success or lack of success of domestic and international anti-corruption activities in Albania?

To begin this discussion and to answer the first question presented in the Introduction, there can be no doubt that official corruption has dominated the country during its entire history. This atmosphere was part of the political culture well before the Communists took power, and it became more open with the beginning of the post-communist period.

We have seen that because of reforms started both domestically and by international efforts, corruption has been reduced, but still is a major problem in Albania. Because of international efforts, modern laws dealing with corruption and honesty in government are not in the books. However, the problem is not with the quality of the laws. Instead, as we have also seen, the problem has been the failure to implement and enforce the laws that are supposed to fight corruption.

This glaring difference between the existing laws and actual reality is due to the way the members of the power elite work the system and the failure of anyone, international or domestic, to do anything about it. All of the new "reform" anti-corruption laws have not "reformed" the power elites to the degree that the public seeks, especially in Albania. Because corrupt officials never admit to anything, and, of course, since no high official has ever been found guilty of corruption pursuant to the modern anti-corruption laws already enacted, they will continue their dishonest ways because they know that nothing will happen to them anyway. Every official pretends that the problem has been addressed and denies the underlying fact that the Albanian public has confidence in the integrity of the political elite.

An example of this "ostrich-like" attitude held by the power elite can be found in the interesting, and at the same time, very painful interview of the ex-Chief of the Supreme Court of Albania Ms. Shpresa Beçaj, taken by Bora Fezgaj (Beçaj- 2010). When she was asked what does she thought about the corruption in the judiciary, and about the fact that due to published reports $60 \%$ of the Albanians do not trust the judicial system, Beçaj replied that: - "My problem is that I think they survey the same people, and the surveys are not very objective. Well, l'd like to tell you this. Throughout my career - I am a citizen first and foremost - and everywhere I have gone and during my experience of more than 15 years in the courthouses in Tirana, people have shown me the utmost respect." As for the question of how is it possible that this reputation for corruption has developed, she answered: - "What is negative becomes widely spread. What is positive is not very interesting and is not reported. I am the Chief Justice of the Supreme Court of Albania. Why doesn't someone approach me with concrete facts and the name of a judge who is allegedly corrupt?"

Beçaj's statements demonstrate a fundamental denial of the problem, and, of course, if one does not admit that a disease exists, it is impossible for him to take measures to cure it. And this is a declaration done by one of the highestlevel personalities in Albania. The same thing can be said about the government. As mentioned earlier in this thesis, the politicians find always a way out. Especially in Albania, they have used as a very effective tool -parliamentary immunitywhich is based in non-liability (members of parliament has a special protection for their freedom of expression and they can say what they feel [freedom of speech] and discuss what they wish [freedom of debate]), and in parliamentary inviolability (the parliament members are protected against any civil, administrative or criminal proceedings for statements or acts unrelated to the exercise of their parliamentary mandates. Therefore, they cannot be arrested and/or prosecuted without the assent of the parliament).

In a report prepared from Mr.Roland Miklau, head of the EURALIUS mission and Melissa Schrainbman, OPDAT mission for parliament members Mr. Bufi and Mr. Rusmajli (representatives of the immunity commission in Albanian Parliament) constitutional changes for restricting and clarifying such immunity were advised. The Albanian Constitution provides for this immunity,(Art. 73 deputies; Art.126 Constitutional Court Judges; Art.137 all other judges ) as enacted in 1998, and prepared with a broad consultation led by a Special Parliamentary Commission, representatives from the Venice Commission of the Council of Europe and the presence of the OSCE in Albania (OSCE 2006). At that time, due 
to the early stage of democracy, maybe it such protection were needed, and this can explain the complete immunity, but in this days there is no such need. These Constitutional articles are now true obstacles to justice. Certainly, soliciting or accepting bribes or other improper payments or benefits, was never "within the scope" of the responsibilities of a deputy, judge or other high official. In their conclusions, the above Europeans recommended that governmental immunity needed to be severely restricted if the problem of corruption was going to be seriously addressed (Miklau; Schraibman-2006).

Since these recommendations, there have been many "debates" on the issue of restricting immunity, but nothing concrete has resulted, and it is doubtful if the political elite is interested in really changing things because it affects their own luxurious way of life. Until this issue is addressed seriously, and until all of the anti-corruption laws are actually enforced, it is submitted that many international "reforms" are really "full of sound and fury signifying nothing".

To actually measure the impact of anti-corruption reforms is not an easy thing to do. Finding the criteria through which the evaluation can be done, is difficult. If go the index of $\mathrm{TI}$ is used, all we can see is that Albania have improved, but not enough to justify all of the specific international efforts to change things. This, therefore, raises the question of whether these projects were worthwhile, as well as the question of whether all this money was spent in the best way possible in order to help this country to overpass their obstacles in the difficult road of meeting European standards.

This brings us to the sad answer to the second question of this thesis. While international efforts have resulted in excellent new laws, too often the "Internationals" have regarded the power elites in Albania as their partners in reform. This, I think, has been a major mistake. The people in the power elites did not get to where they are, because they are stupid. Why would they want to give up their personal privileges? So, what happens is that international organizations bring into Albania "experts" in government reform, but rarely have any understanding of the culture of Albania. They come into the country with laws copied from their countries and think that if these laws are put into place, the problem of corruption will be addressed. The power elites politely listen to the international experts, agree to the new laws and actually cause the laws to become part of Albanian law. The "experts" return to their home countries with something new to add to their CVs, and meanwhile, back in Albania, the new reform laws are simply not enforced or the politicians have no trouble getting around them. Then the international organizations return to Albania with new "programs" dealing with the exact same corruption issues and the process starts all over again.

Therefore, it is only when international organizations do something to see that things are done fairly, like the OSCE with elections, that they become real forces of change, but when they make the same recommendations, but really do not do anything, all of the power stays with the political elite, who usually does not have the political will or the motivation to make any real changes.

International organizations are beginning to realize that this is the case and have slowly become more concerned that the laws dealing with corruption and honesty are actually enforced, or else they won't give as much foreign assistance as they did right after the fall of Communism.

Finally, this takes us to the third question of the thesis. I have already discussed to what extent international entities like the EU and the United States should be blamed for their failure to see that good laws were being actually being enforced. The question remains whether credit should be given to European and American efforts where anticorruption efforts have been successful in Albania.

First, anti-corruption efforts have only been partially successful. In those instances where they were successful because of direct international involvement, like OSCE in elections, much credit should be given to the international organization.

Second, where international efforts only involved recommendations, and not assistance in enforcing anticorruption laws, I am uncertain how much credit should be given to such efforts. If you want to be an optimist, then you can certainly say that at least the international organizations should be given credit for helping to create a climate for change.

Third, as seen any important reaction to public scandals do not come from international efforts, but come from public reaction against corruption. While corruption has always been a major problem in Albania, people have made it clear that they will not tolerate this injustice anymore. This has happened because of the free media that has become a part of Albanian life.

This growing frustration with corruption is also due to more access to the Internet, greater travel abroad by Albanians (including students), and more people working abroad. Unlike the Communist days, especially for Albania, the people now are able to see how other countries work and can make their own comparisons. While international efforts, when used correctly, can be very helpful, there is only so much pressure that the EU and the United States are willing to put on the power elites to change. Until international organizations are able to convince the power elites that they need to change for their own good, the most important agent for change will continue to be the Albanian people themselves. 


\section{References}

Bideleux R. and Jeffries I., (2007) "A History of Eastern Europe: Crisis and Changes", New York : Taylor\&Francis.

Bogdani M. and Loughlin J. (2004), "Albania and the European Union. European Union: European Integration and the Prospect of Accession" Tirana: Daiti

Bogdani M. and Loughlin J. (2007), "Albania and the European Union. The Tumultuous Journey Towards Integration and Accession" New York : I.B.Tauris\&Co.

R.W.Seton-Watson, (1962), "Disraeli, Gladstone and the Eastern Questions: A study in Diplomacy and Party Politics" , London : Frank Cass.

Stavrianos L.S,(1957), "The Balkans Since 1453", New York: Holt, Rinehart and Winston.

Furlong P., (1994), "Modern Italy. Representation and Reforms”, USA, Canada : Routledge.

Institute of Marxist-Leninist Studies, (1980), "History of the Party of Labour of Albania", Tirana.

Newell J., (2000), "Parties and Democracy in Italy", Dartmouth : Ashgate.

Palmer A. (1970), "The Lands Between" New York: The Macmillan Company.

Wolf R. L., (1967), "The Balkans in Our time", New York : W.W.Norton.

Vickers M.; Pettifor J., (2000), "Albania: From Anarchy to a Balkan Identity" United Kingdom : C. Hurst \& Co.

Carver R. (1999) "The Accursed Mountains: Journeys in Albania" UK: HarperCollins.

The Economist, 2005, "Berisha Beacon" 07.09.2005. - 00130613. - 8434 : Vol. 376. retrieved from http://www.economist.com/node 14154570

R.W. H Seton-Watson(1962), "Eastern Europe Between the Wars 1918-1941", Cambridge;Cambridge University Press, Third Edition.

Janos A. (1989), "The Politics of Backwards in Continental Europe 1780-1945" Cambridge : World Politics, - 3 : Vol. 41 retrieved from http://journals.cambridge.org/action/displayAbstract?fromPage $=$ online\&aid $=7546400$

Kopstein S. Jeffrey; Reilly A. David "Geographic Diffusion and the Transformation of the Post-Communist World" - Colorado:University of Colorado at Boulder. - CO 80309-0333.

McFaul M. (2002) "The Fourth Wave of Democracy and Dictatorship: Non-Cooperative Transitions in the Post-Communist World", Cambridge: World Politics. - 2 : Vol. 54.

Mouro P. (1995) "Corruption and Growth", The Quarterly Journal of Economics, - 3 : Vol. 110.

Peçi I. ; Sikkema E. (2010) "Corruption and legal certainty; the case of Albania and the Netherlands Implementation of the Criminal Law Convention on Corruption in a Transitional and Consolidated Democracy", Utrecht : Utrecht Law Review, - 1: Vol. 6, retrieved from http://www.utrechtlawreview.org/ Volume 6, Issue 1 (January) 2010

Stark D, ; Bruszt L. (1989), "Post-socialist Pathways: Transforming politics and property in East Central Europe", Cambridge: Cambridge University Press.

Miklau R. ; Schraibman M. (2008), "Immunity”, Tirana : Euralius\&Opdat.

Fourlanos G. ; Horn H. ; Weeda E. (2005) "Evaluation Report on Albania: Second Evaluation Round", Strasbourg: Council of Europe.

PACO Impact Project (July 2006), "Final Report" 2004-2006) Brussels : Council of Europe.

"International Cooperation to Fight Corruption in South Eastern Europe", Basel: Basel Institute on Governance, (February 2005) retrieved from www.anticorruptionnet.org

Gerassimos F., Henrik H., Eline W. (18 March 2005) "Second evaluation Round Strasburg"

Albanian Parliament (1998) "Albanian Constitution.",Tirana :Qendra e Publikimeve Zyrtare.

Loloçi K., (2006), "Debati kushtetues. Diskutimet e Zhvilluara ne Mbledhjet e Komisionit Parlamentar per Hartimin e Prolekt-kushtetutes", mars-shtator 1998 Tirana : OSCE.

Beçaj Sh. "The Frustrations of Albania?Top Criminal judge" : Fezga Bora ; online, August 30, 2010, checked 10 of June 2011; Full Text Available By: Fezga B. Transitions Online, 8/30/2010, p5-5, 1p

Qendra e Publikimeve Zyrtare (2009), "Kodi i Punes i Republikes se Shqiperise", Tirana : Qendra e Publikimeve Zyrtare.

Woods A. (1997) "The meaning of the Albanian Revolution." - London : 16-03-1997, retrieved from http://www.marxist.com/Europeold/albania2.html

OSCE 2006 "Debati kushtetues" (The constitutional debate). Edited by a member of the technical drafting group, and is so far only in the Albanian language

Gjykata e Tiranes // gjykatatirana.al. - 2011.

http://www.balkanweb.com/index.php?id=60582, accessed on 01 May 2011

http://www.forumishqiptar.com/showthread.php?t=48734 17 April 2005, gazeta "Korrieri", accessed on 14 April 2011

http://www.shekulli.com.al/2011/04/13/mercenarizem-pervers.html Bledar H. Prifti 13/04/2011, source used on 15 May 2011

http://www.panorama.com.al/2011/07/23/gjyqtaret-e-prokuroret-blejne-makina-e-shtepi/, source used on 15 May 2011

http://iliriada.createmyboard.com/t265-komente-durres-prishtinearteria-e-ballkanit Sokol, Beja 01/02/2008, accessed on 25 April 2011

http://www.irex.org/programs/MSI EUR/archive.asp accessed on 10 May 2011

http://en.wikipedia.org/wiki/Lulzim_Basha source used on 15 May 2011

http://www.gazeta-albania.net/news.php?id=11476 Accessed on 10 May 2011 


\section{Appendix}

\section{Abbreviations}

NATO-North Atlantic Treaty Organization CoE-Council of Europe

OECD - Organization for Economic Co-operation and Development

WB- World Bank

SPAI - Pact Anti-Corruption Initiatives

PACO- Program Against Crime in South-Eastern Europe

CARDS- Community's Assistance for Reconstruction, Development and Stabilization USAID - United States Agency for International Development

IPL- Albanian Institute for Policy and Legal Studies

GRECO- Group of States Against Corruption

TI- Transparency International ACMG- Anti-Corruption Monitory Group

ACAC - Albanian Coalition Against Corruption

COA - Citizens Advocacy Office 